\title{
Learning to Read with the Whole Language Approach: The Teacher's View
}

\author{
Ling-Ying, Huang ${ }^{1}$ \\ ${ }^{1}$ Graduate School of Education, University of Exeter, UK \\ Correspondence: Ling-Ying, Huang, Graduate School of Education, University of Exeter, UK. E-mail: \\ linhuang216@hotmail.com
}

Received: January 30, 2014 Accepted: March 2, 2014 Online Published: April 14, 2014

doi:10.5539/elt.v7n5p71 URL: http://dx.doi.org/10.5539/elt.v7n5p71

\begin{abstract}
This project explores the understanding of early year's teachers regarding whole language approach and its implementation. A total of 200 questionnaires were delivered to teachers at nurseries and kindergartens in an EFL (English as a Foreign Language) context. 169 questionnaires were completed and analysed. The findings shows that an overwhelming majority of the participants know idea of whole language approach and know its value and relevance to improving early year literacy teaching. The result showed that teachers' perspective about literacy teaching clustered primarily in the interactive approach which indicated that most teachers prefer neither whole language approach nor skills based approach.
\end{abstract}

Keywords: whole language, primary education, literacy

\section{Introduction}

The whole language approach has in recent times been a very popular and important trend in early childhood education. Researchers of the whole language philosophy hold the view that language should not be broken down into letters or combinations of letters and ordinary understandable message decoded. Instead, they believe that language is a complete system of making meaning, with words functioned in relation to each other in context. Many nurseries even put the whole language approach as one of the important elements in their curriculum design in order to attract more parents when they were looking for early childhood education programmes for their children (Liu, 2006). This study seeks to offer a platform for teachers, educators and researchers to go beyond the superficial realization of the difficulties of putting change into practice. The researcher felt a passionate desire to pursue a study with the primary research purpose of investigating the implementation of the changes to nursery literacy learning and teaching practices. What difficulties had they encountered in terms of integrating the whole language approach into their programmes? Where were the difficulties for teachers in making these changes to practice in nursery classrooms? If why and how do they emerge? These questions represent the key foci of the current study. How to approach these questions is central to the organization and scope of the research.

\section{Literature Review}

\subsection{Whole Language Approach}

The whole language proponents claimed that language should not be broken down into letters and combinations of letters and decoded (Stahl \& Miller, 1989). Instead, they believe that language is a complete system of making meaning, with words functioning in relation to each other in context (Moats, 2007). Froses (1991, p. 2) defines "whole language" as a:

child centered, literature-based approach to language teaching that immerses students in real communication situations whenever possible.

It also suggests that language is learned from whole to part. Learners are presented with whole and natural language (Bergeron, 1990). The philosophy of whole language approach is complex and draws on fields such as education, linguistics, psychology, sociology, and anthropology (Jeynes \& Littell, 2000; Juel \& Minden-Cupp, 2000). As Adams claims, whole language movement:

... should be a core component of a long overdue and highly constructive revolution. It should be about restoring 
the confidence and authority of teachers. It should be an affirmation that education can only be as effective as it is sensitive to the strengths, interests and needs of its students. (Adams, 1991, p. 41)

P. Stanovich and K. Stanovich (1999, p. 29) echo this sentiment:

The way now seems clear for the whole language advocates to reconstitute their position in a scientifically respectable way. They could retain most of their broad socio-educational goal (teacher empowerment, equal opportunity for all learners, engaged learning etc)

\subsection{Top-Down Reading Approach to Whole Language Approach}

The whole language approach is based on constructivist learning theory and is often considered a top-down model. The concept of whole language is strongly associated with the work of Goodman (1967). Goodman's conceptualization departs from an older perspective on reading acquisition in that it sees the process of learning to read as behavioural and maturing process. Goodman (1986) stated that reading and writing involve children learning in any social context that enables them to develop literacy before they start formal school instruction in reading and writing. As Goodman (1986) reports that when shown familiar environmental print, such as cereal boxes, familiar logos and signs, $60 \%$ of 3 year olds and 80 percent of 5 year olds could read. It is clear that before any concepts associated with the fine-grained decoding of text can hold any significance, children do need to have a more basic awareness of print.

\subsection{Bottom-Up vs. Top-Down Approaches}

Arguments between what have been termed bottom-up and top-down approaches (Smith, 1971; Goodman, 1986) have historically held a central position in the debate about the teaching of reading in the West. Stanovich and Stanovich (1999) have described these debates as the reading wars, and suggested that whole language versus phonics-emphasis controversy of the last decade has "generated acrimony, sapped the field's energies and most important of all, confused and demoralized educators" (1999, p. 12). Before starting the whole language approach (top-down model) it may be useful to introduce some of the central ideas of the bottom-up model. Briefly, the bottom-up model assumes that the process of learning to read starts with the recognition of letters then clusters of letters, then words and so on progressively until finally a whole text can be processed. Taken at its most extreme, the assumption can be that the concepts and skills are acquired in a step-by-step process, requiring a careful and cumulative introduction to the elements of written language: fist letters, then words, then phrase or sentences and then stories and books in a linear fashion (Gough, 1972).

Smith (1971) and Goodman (1976) criticize the bottom-up model believing to lead to an over-emphasis on decoding at the expense of other skills and concepts. Furthermore, a major problem with the extreme bottom-up model lies with the model of knowledge and learning it appears to assume. It does not fit with the large and influential corpus of current thinking, which does not believe that knowledge can be described as a series of chunks that are acquired one after another (Bruner, 1996). In understanding literacy as a social practice, the focus has shifted from viewing language and literacy as a set of rules to using literacy in authentic events. Reading and writing are considered elements of larger practices that are socially patterned and cognition in literacy learning is seen as guided by social participation and relationships (Gee, 1996; Barton \& Hamilton, 2000). To properly understand literacy processes one must locate them within interactions of social and cultural practices, that is, literacy learning occurs through social interactions and relationships with others (Street, 1984). The child is not considered as an empty vessel to be gradually filled by the teachers, but as partners in the social process of literacy learning (Berger, 2005). Dyson (2001) argued that literacy learning should begin with children's social worlds. Learning about print knowledge, or gaining knowledge about reading and writing, can occur in many different contexts.

\section{Research Method}

This research employed a means of questionnaire was to gain an overall picture of many teachers' perceptions of teaching literacy and children's literacy learning from a large sample. This would act as a springboard for more qualitative methods such as interview and observation to provide a greater in-depth picture of the phenomenon (Cohen, Manion, \& Morrison, 2011).

200 questionnaires were distributed to nursery, preschool and kindergarten between September 2008 and January 2009 in Taiwan. A total of 173 were returned but 4 had to be rejected due to incomplete information. Therefore, 169 questionnaires (84\%) were completed and analyzed. The questionnaire was divided into two sections. The first included introductory questions to find out if the sample represented a normal range of early year's practitioners; the second section consisted of 17 items to assess early-years teachers' literacy instruction in their daily teaching classroom. The last section consisted of 24 items to explore teachers' beliefs about literacy. 
In the questionnaire section one, the teachers assessed their own approach to teaching literacy. A seven point continuum was given with the whole language and child centered approaches at one end and traditional skills based and a teacher-directed approach at the other end. The respondents were asked to tick a box which most represented their own approach to teaching.

The second section of the questionnaire is about teacher's course design for whole language approach activities. There were altogether 17 statements and the respondents were asked to rank them on a 4 point Liker-scale in order of importance, from the most important to the least important, or from very often to not often, as appropriate. The seventeen statements covered a wide range of teaching behaviour in the classroom. Some were associated more with whole language and a child centered approach; others with a skills-based, teacher-directed approach. With a 4-point Likert scale, a mean above 3 would indicate a generally positive answer to the statement while a mean below 2 would mean a negative answer. Furthermore, the four answers (very often, often, not quite often or not often) are also grouped into two, general tendency, groups. The reason for re-grouping the responses in this way is that, firstly, a 4-point Likert scale has no midpoint to follow or for comparison.

\section{Data Analysis}

The questionnaire results were analysed under the following headings:

1) Teacher's reactions towards the whole language in the literacy classroom

2) Teacher's approach of assessing their own approach to teaching literacy

3) Teacher's decision making in the literacy classroom

4) Teacher's perceptions of literacy

5) Availability of resources in the school

6) Teachers' reported practices in the literacy classroom

\subsection{Teacher's Reactions towards the Whole Language in the Literacy Classroom}

The result in Figure 1 shows that over half of teachers $50.3 \%$ approved of and agreed with the idea of the whole language approach.

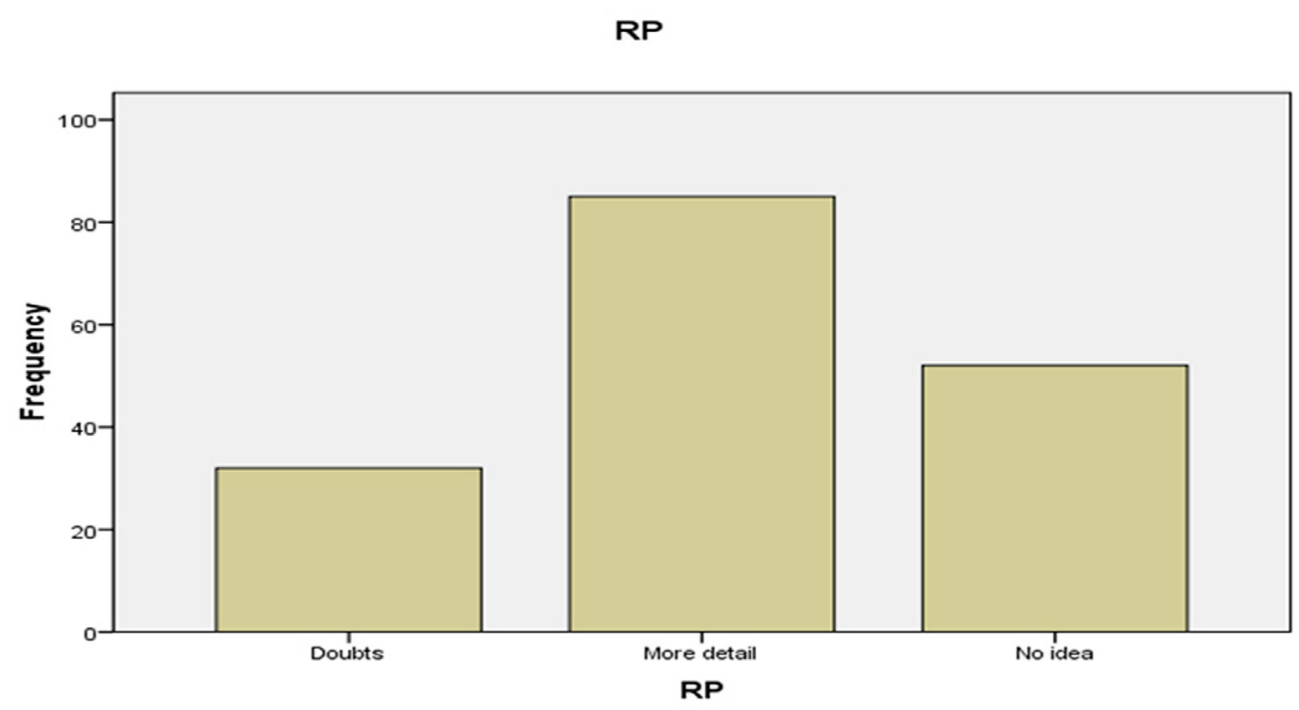

Figure 1. Conception of whole language approach

Moreover, $30.8 \%$ of the teachers said that they were not sure what the whole language approach is, how it could work or how it could be successfully implemented, so they reported that they had some reservations and were doubtful at the same time. On the other hand, only $18.9 \%$ of the respondents expressed any explicit doubts and reservations towards the new approach. However, this result also showed some of the extra comments made by the teachers while answering the questionnaire about literacy teaching and the whole language approach. These comments was given by those who chose "others" in this section, then giving the reason that teachers are 
confident in coping with literacy lessons and in handling the process of changing. However, these teachers suggest the notion or inspiration should be promoted in more detail and be more practical as they desire more detailed information.

\subsection{Teacher's Approach of Assessing Their Own Approach to Teaching Literacy}

In the questionnaire, the teachers were asked to assess their own approach to teaching literacy. A seven point continuum was given with the whole language and child centered approaches at one end and traditional skills based and a teacher-directed approach at the other end. The respondents were asked to tick a box which most represented their own approach to teaching. As Table 1 shows, only 6 of the $169(3.6 \%)$ teachers reported that they employed a fully traditional skills-based and teacher-directed approach.

Table 1. Teachers access their approach to teaching literacy

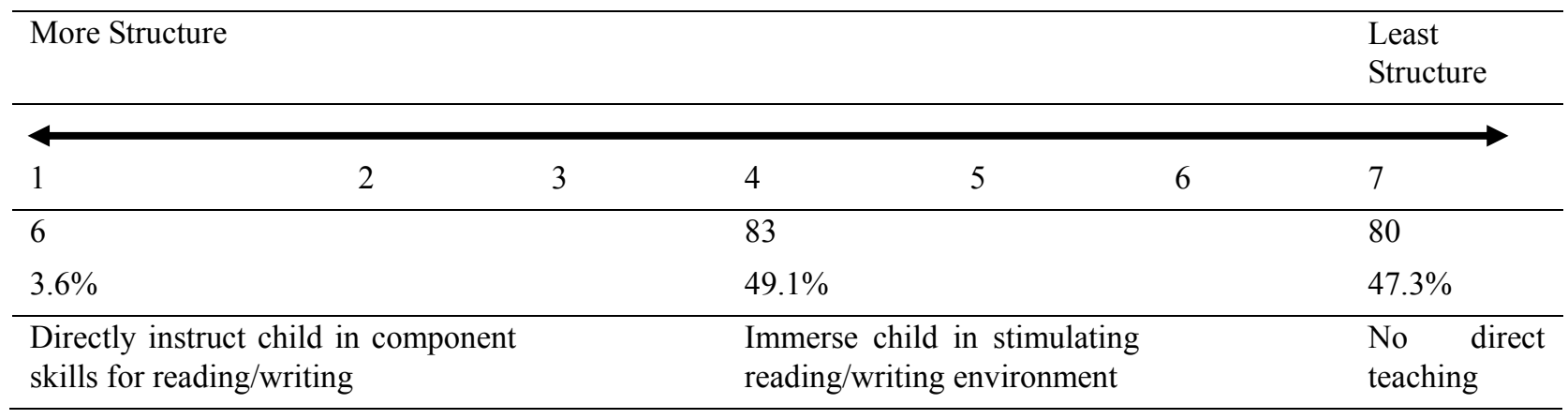

The rest of the majority reported themselves to be between the two extremes, with $47.3 \%$ more closely identifying with the whole language children-centered approaches, while $49.1 \%$ fell between the two extremes. The results show in Table 1 that teachers' choices were clustered towards the middle and were divided between a traditional skills-based approach and the whole language approach.

\subsection{Teacher's Decision Making in the Literacy Classroom}

When asked about teachers' decision making in the literacy lesson regarding lesson content and material choice, the results show that $55 \%$ of the respondents said that they were following the school's own principles and the teacher's manual showed in Table 2.

Table 2. Teachers decision making in the literacy classroom

\begin{tabular}{lll}
\hline Decision making $(\mathrm{n}=169)$ & Count & $\%$ \\
\hline Government curriculum/ standard & 3 & $1.8 \%$ \\
School principles or policy (Teachers manual) & 93 & $55 \%$ \\
children's interest/needs & 73 & $43.2 \%$ \\
\hline
\end{tabular}

Another $43.2 \%$ of teachers said that they depended on the children's interest and supported what children the liked and needed. A small number of the teachers $(1.8 \%)$ claimed that they followed the government's curriculum standards.

\subsection{Teacher's Perceptions of Literacy}

The respondents were presented with five items and chose as many as they liked to indicate the reasons why literacy teaching was good thing. For example, indicating whether literacy means receiving knowledge, or remembering knowledge, or constructing meaning through experience and interaction. Altogether, five statements were given and the respondents were offered multiple choices, as they were asked to choose as many as they believed could best represent the importance of literacy to them. Table 3 shows the teacher's perceptive of literacy. 
Table 3. Teachers perceptions of literacy

\begin{tabular}{lll}
\hline The reasons why literacy is good for you $(\mathrm{n}=169)$ & Count & $\%$ \\
\hline To receive knowledge to become knowledgeable. & 134 & $79 \%$ \\
To cope with textbooks and exams. & 89 & $53 \%$ \\
To find out truth with effort and pleasure. & 141 & $83 \%$ \\
To help in work. & 145 & $86 \%$ \\
To demonstrate positive attitudes to others. & 118 & $70 \%$ \\
\hline
\end{tabular}

An overwhelming consensus was found in the belief that literacy is good for pupils: to help with work (86\%), to find out truth with effort and pleasure (83\%), and to receive knowledge to become knowledgeable (79\%). At the same time, a large number of the respondents $(118$, over $70 \%)$ selected to demonstrate positive attitudes to others and to cope with textbooks and exams (53\%), reflecting the traditional Confucian conception of literacy learning, which is to become a knowledgeable role model.

\subsection{Availability of Resources in the School}

The results show that $90.6 \%$ of the teachers are of the opinion that their schools in general have sufficient resources of books in the school main libraries rather than individual classroom literacy corners. Based on the result of a more specific question about the individual classrooms, $65.2 \%$ of the teachers mention that they do not have enough books and reading materials in their classroom literacy corners; only $34.8 \%$ of the teachers claimed they had enough literacy resources. These figures indicate that many, if not most, of early year classroom literacy corners still lack sufficient books and materials.

\subsection{Teachers' Reported Practices in the Literacy Classroom}

Based on the responses to the second section of the questionnaire it appears that what the respondents reported and believed was reflected in their responses to the statements on classroom practices. In order to get a clearer picture of the views expressed by these teachers, the results are presented in two separate tables (Table 4 and Table 5) to show the results in descending order based on mean averages.

Table 4 shows the mean, SD, percentage of agreement and mode scores of the cluster of 9 items for the whole language approach and child-centered practice.

Table 4. Descriptive statistics for whole language approach activities

\begin{tabular}{|c|c|c|c|c|c|}
\hline $\begin{array}{l}\text { Item } \\
\text { No. }\end{array}$ & Item description $(n=169)$ & Mean & SD & Agree $\%$ & MODE \\
\hline 14 & I often ask pupil to join the reading or library area & 3.54 & .732 & $91.7 \%$ & 4 \\
\hline 1 & Pay special attention to children's interests in literacy & 3.53 & .557 & $97 \%$ & 4 \\
\hline 11 & $\begin{array}{l}\text { I often read story to my pupil and also create opportunities for } \\
\text { them to share and express. }\end{array}$ & 3.46 & .598 & $95.8 \%$ & 4 \\
\hline 4 & Using children's book & 3.44 & .606 & $95.3 \%$ & 4 \\
\hline 13 & $\begin{array}{l}\text { I create opportunities and encourage children to express and } \\
\text { share their own ideas, feeling or opinions }\end{array}$ & 3.23 & .645 & $90.5 \%$ & 3 \\
\hline 7 & Using a mix of materials & 3.18 & .792 & $83.4 \%$ & 3 \\
\hline 12 & I often introduce new vocabulary based on a familiar story book. & 3.03 & .812 & $81.7 \%$ & 3 \\
\hline 8 & Using Children's newspaper or magazine & 2.30 & 1.004 & $46.7 \%$ & 3 \\
\hline 9 & Using audio book or e-resources & 2.18 & 1.062 & $45.6 \%$ & 2 \\
\hline \multicolumn{2}{|c|}{ Overall average of mean } & 3.10 & & & \\
\hline
\end{tabular}

The overall scores averaged 3.10 on the 4-point scale, which is moderately toward the high agreement side of the scale. In fact, seven of the nine items show agreement within the range of $81.7 \%$ to $97 \%$. The strongest rating was for Item 1, for which $97 \%$ of teachers agreed with the statement about paying great attention to children's 
interests in literacy. Also, the majority of teachers positively agreed with items 14,1112 , which were statements regarding the use of stories and library materials to encourage pupils to express themselves and engage with the vocabulary learning. At the same time, a large majority of respondents claimed that they create opportunities for interaction in the classroom (Item 13: $90.5 \%$ of teachers).

On the other hand, teachers tended to disagree with items 8 and 9, statements about the use of children's newspapers, magazines or audio books and any e-resources. All the above statements of teaching behaviour were closely associated with the whole language and children-centred approaches, except those presented in Table 5 below. Here, it seems that teachers were asking children to do a lot of repetition and imitating, often considered to be part of the traditional approach, which was also frequently observed in literacy lessons. Table 5 demonstrates that the majority see value in skills-based activities for classroom practice.

Table 5. Descriptive statistics for skills based activities

\begin{tabular}{|c|c|c|c|c|c|}
\hline $\begin{array}{l}\text { Item } \\
\text { No. }\end{array}$ & Item description $(n=169)$ & Mean & SD & Agree $\%$ & MODE \\
\hline 3 & $\begin{array}{l}\text { Stress on good rules and try to keep good order during class } \\
\text { time }\end{array}$ & 3.52 & .557 & $98.20 \%$ & 4 \\
\hline 5 & I often using textbook & 3.43 & .843 & $89.90 \%$ & 4 \\
\hline 2 & Pay entire attention to skill based practice & 3.30 & .543 & $95.9 \%$ & 3 \\
\hline 6 & I often use flash cards & 3.28 & .866 & $85.80 \%$ & 4 \\
\hline 15 & $\begin{array}{l}\text { I often keen in give lesson and explain vocabulary, phonics } \\
\text { most of the time then pupils do some focused practice. }\end{array}$ & 3.12 & .999 & $84 \%$ & 3 \\
\hline 10 & I often use a skills practice book and work book & 2.88 & 1.051 & $71.60 \%$ & 3 \\
\hline 16 & $\begin{array}{l}\text { I often ask my pupils to recite. Coping and practicing words } \\
\text { helps memorization. }\end{array}$ & 2.79 & 1.023 & $73.40 \%$ & 3 \\
\hline 17 & $\begin{array}{l}\text { In class, most of the time pupil do a lot of repetition and } \\
\text { drilling after my talk to practice new words and dialogues }\end{array}$ & 2.36 & 1.136 & $54.40 \%$ & 2 \\
\hline \multicolumn{2}{|c|}{ Overall average of mean } & 3.9 & & & \\
\hline
\end{tabular}

The data show that in seven of the eight items, teachers agreed with the statements. The skills-based activities most likely to be carried out are those identified in items 3, 5, 2, 6, 15, 10 and 16. However, teacher responses to item 17 were relatively divided (54.40\%). Specifically, this statement was about practices discussed in the research literature as predominantly supported by skills-based advocates. According to the data, this statement reflected a separate view in practice, relating to asking children to frequently repeat and imitate.

The overall data in Tables 4 and 5 show that teachers' classroom practice of literacy teaching was mostly an interactive approach, indicating that most teachers prefer neither the whole language approach nor a skills-based approach. They report that they teach with a blend of methods and techniques drawn from both approaches.

\section{Conclusion}

The findings of the Teacher Questionnaire give a snapshot of the main tendencies informing teachers' perspective of literacy teaching and learning clustered primarily in the interactive approach. The analysis indicated that most teachers prefer neither the traditional skills-based approach/teacher-directed view of literacy teaching, nor the social interaction/whole language view of literacy teaching and learning. They used a blend of methods and techniques, drawing from both the whole language approach and the skills-based approach. The questionnaire acted as a way of understanding teachers' lives. Further studies are necessary to investigate teacher's beliefs and their practice of the whole language approach in the classroom.

\section{References}

Adams, M. J. (1991). Why not phonics and whole language? In W. Ellis (Ed.), All language and the creation of literacy (pp. 40-53). Baltimore, MD: Orton Dyslexia Society. two

Barton, D., \& Hamilton, M. (2000). Local literacies: Reading and writing in one community. London: Routledge. 
Berger, C. R. (2005). Interpersonal communication: Theoretical perspectives, future prospects. Journal of Communication, 55, 415-447. http://dx.doi.org/10.1111/j.1460-2466.2005.tb02680.x

Bergeron, B. S. (1990). What does the term whole language mean? Constructing a definition from the literature. Journal of Reading Behavior, 12(4), 301-329.

Bruner, J. S. (1996). The culture of education. Cambridge, MA: Harvard University Press.

Cohen, L., Manion, L., \& Morrison, K. (2011). Research Methods in Education (7th ed.). London: Routledge Falmer.

Dyson, A. (2001). Where are the childhood in childhood literacy? An exploration in outer (school) space. Journal of Early Childhood Literacy, 1(1), 9-30. http://dx.doi.org/10.1177/14687984010011002

Froese, V. (1991). Whole Language Practice and Theory. Boston: Allyn and Bacon.

Gee, J. P. (1996). Social linguistics and literacies: Ideology in discourses. London: Taylor \& Francis.

Goodman, K. S. (1986). What's Whole in Whole Language? Portsmouth: Heinemann.

Goodman, K. S. (1967). Reading: A Psycholinguistic Guessing Game. Journal of the Reading Specialist, 6, 126-135. http://dx.doi.org/10.1080/19388076709556976

Gough, P. B. (1972). One second of reading. In J. F. Kavanagh, \& I. G. Mattingly (Eds.), Language by ear and by eye (pp. 331-358). Cambridge, MA: MIT Press.

Jeynes, W. H., \& Littell, S. W. (2000). A meta-analysis of studies exa mining the effect of whole language instruction on the literacy of low-SES students. Elementary School Journal, 101, 21-33. http://dx.doi.org/10.1086/499657

Juel, C., \& Minden-Cupp, C. (2000). Learning to read words: Linguistic units and instructional strategies. Reading Research Quarterly, 35, 128-134. http://dx.doi.org/10.1598/RRQ.35.4.2

Liu, S. (2006). An Examination of the effects of print media exposure and contact on subjective social reality and acculturation attitudes. International Journal of Intercultural Relations, 30(3), 365-382. http://dx.doi.org/10.1016/j.ijintrel.2005.08.007

Moats, L. (2007). Whole language high jinks: How to Tell When "Scientifically-Based Reading Instruction" Isn't. Washington, DC: Thomas B. Fordham Institute.

Smith, F. (1971). Understanding Reading. New York: Holt, Rinehart and Winston.

Stahl, S., \& Miller, P. (1989). Whole Language and Language Experience Approaches for Beginning Reading: A Quantitative Research Synthesis. Review of Educational Research, 59(1), 87-116. http://dx.doi.org/10.3102/00346543059001087

Stanovich, K. E., \& Stanovich, P. J. (1999). How research might inform the debate about early reading acquisition. In J. Oakhill, \& R. Beard (Eds.), Reading development and the teaching of reading: A psychological perspective (pp. 12-41). Oxford: Blackwell Publishers.

Street, B. (1984). Literacy in theory and Practice. Cambridge: Cambridge University Press.

\section{Copyrights}

Copyright for this article is retained by the author(s), with first publication rights granted to the journal.

This is an open-access article distributed under the terms and conditions of the Creative Commons Attribution license (http://creativecommons.org/licenses/by/3.0/). 